\title{
REKONSTRUKSI HUKUM WARIS ISLAM (Telaah Pemikiran Muhammad Syahrur)
}

\author{
Afif Muamar \\ Fakultas Syari'ah dan Ekonomi Islam \\ Institut Agama Islam Negeri Syekh Nurjati Cirebon \\ email:afifmuamar85@yahoo.com
}

\begin{abstract}
Abstrak
Dalam menjawab perubahan konteks sosial, pemikiran Muhammad Syahrur dengan kerangka dan metode yang berbeda dengan metode-metode pioner pemikiran hukum Islam lainnya hadir dalam rangka merekonstruksi hukum waris Islam. Di satu sisi, Syahrur hendak membaca kembali hukum waris Islam dengan pembacaan kontemporer, sehingga tidak jarang hasilnya berbeda dengan para fuqaha pada umumnya. Di lain pihak, ia mengkritik pemikiran hukum waris Islam untuk kemudian merekonstruksinya, baik dari sisi hukumnya maupun historisitasnya. Temuan Syahrur tentang teori batas (theory of limits), yang disebutsebut sebagai sumbangan utama dalam bidang Ushul Fiqh, membawa implikasi besar terhadap berbagai pembacaan dan kesimpulan hukum Islam, termasuk dalam hukum waris Islam. Untuk mengungkap pemikiran Syahrur, maka jenis penelitian yang digunakan adalah penelitian kepustakaan, yaitu mencari data dari berbagai literatur dan referensi yang berhubungan dengan materi pembahasan. Adapun pendekatan yang digunakan adalah pendekatan kualitatif-normatif dan teknik dalam menganalisis berupa analisis deskriptif. Tiga aspek yang menjadi temuan penting di sini adalah; pertama, terkait relasi wasiat dan waris, menurut Syahrur, wasiat harus diutamakan daripada waris, karena lebih bisa mengakomodir nilai-nilai keadilan; kedua, tidak ada nasakh terhadap ayat-ayat wasiat; ketiga, teori batas Syahrur berimplikasi pada runtuhnya pandangan lama bahwa bagian-bagian waris sama sekali tidak bisa diubah.
\end{abstract}

Kata Kunci: Konteks Sosial, Rekonstruksi Hukum Waris Islam, dan Teori Batas.

\begin{abstract}
:
In responding to the changing social context, the thought of Muhammad Syahrur with a framework and method different from other pioneering methods of Islamic legal thought is present in order to reconstruct the Islamic inheritance law. On the one hand, Syahrur is about to re-read the Islamic inheritance law with contemporary reading, so it is not uncommonly different with the fuqaha in general. On the other hand, he criticized the Islamic law's inheritance law to reconstruct it, both in terms of law and its historicity. Syahrur's findings on the theory of limits, which are touted as major contributions in the field of Ushul Fiqh, bring great implications to various readings and conclusions of Islamic law, including in the Islamic law of inheritance. To reveal the thoughts of Syahrur, then the type of research used is literature research, which is looking for data from various literatures and references related to the subject matter. The approach used is a qualitative-normative approach and techniques in analyzing the form of descriptive analysis. Three aspects that are important findings here are: first, in relation to wills and inheritance relations, according to Syahrur, the testament must take precedence over inheritance, because it is more able to accommodate the values of justice; secondly, there is no nasakh against the verses of the testament; Third, the theory of limits Syahrur has implications for the collapse of the old view that the inheritance parts are totally unalterable..
\end{abstract}

Keywords: Social Context, Reconstruction of Islamic Inheritance Law, and Theory of Limits. 



\section{PENDAHULUAN}

Hukum Islam telah memberikan aturan begitu rinci dan sistematis mengenai hukum kewarisan. Tidak hanya dalam soal siapa pewaris dan yang berhak mewarisi, hukum waris Islam juga mengatur tentang apa yang diwariskan dan berapa masingmasing bagian ahli waris secara detail. Perincian dan sistematisasi ini nampak kokoh dalam salah satu cabang ilmu dalam hukum Islam, yaitu 'ilm faraidl.

Namun, meski hukum warissebagai ilmu — sudah lama dimapankan, bukan berarti ia lepas dari kritik, terutama bagi para sarjana kontemporer (Muslim maupun non-Muslim). Hukum waris Islam konvensional seringkali menjadi sasaran kritik untuk kemudian merekonstruksinya, baik dari sisi hukumnya maupun historisitasnya.

Salah satu tokoh yang andil memberikan kritik dalam hukum pewarisan adalah Muhammad Syahrur (Syahrur). ${ }^{1}$ Tanpa bermaksud mengecilkan peran dan kontribusi sarjana atau ulama lainnya, pemikiran Syahrur menarik untuk diteliti lebih lanjut.

Sementara itu, Syahrur sudah tidak diragukan lagi kontroversi dan pengaruhnya di dunia Muslim. Ia merupakan ulama kontemporer yang berusaha membaca kembali hukum Islam dan merekonstruksinya dengan pembacaan kontemporer, yang tidak jarang hasilnya berbeda dengan para fuqaha pada umumnya. Syahrur sendiri sering disandingkan dengan ulama kontemporer lainnya, seperti Muhammad Said Asymawi (Asymawi), Fazlur Rahman (Rahman) dan Abu Zayd. Temuannya tentang teori batas (theory of

${ }^{1}$ Gagasan Syahrur tentang hukum waris Islam bisa dilacak dalam berbagai karyanya, misalnya dalam al-Kitab wa al-Qur'an: Qira'ah Mu'ashirah (Damaskus: al-Ahali li ath-Thiba'ah li an-Nasyr wa at-Tauzi, 1992), yang diterjemahkan menjadi Prinsip dan Dasar Hermeneutika Hukum Islam Kontemporer, terj. Sahiron Syamsuddin dan Burhanudin Zikri (Yogyakarta: eLSAQ Press, 2007), dan Nahw Usul Jadidah Li al-Fiqh al-Islami, yang diterjemahkan menjadi Metodologi Fiqih Islam Kontemporer, terj. Sahiron Syamsuddin dan Burhanudin (Yogyakarta: eLSAQ Press, 2004). limits, $h u d u>d$ ), yang disebut-sebut sebagai sumbangan utama Syahrur dalam bidang Ushul Fiqh, ${ }^{2}$ membawa implikasi besar terhadap berbagai pembacaan dan kesimpulan hukum Islam-termasuk hukum waris-yang berbeda dengan pandangan para fuqaha sebelumnya. Selain mengkritik para fuqaha yang menempatkan aturan wasiat di bawah warisan, Syahrur juga membongkar sistem pembagian harta warisan yang "kaku". Bagi Syahrur, bagian laki-laki dan perempuan $(2: 1)$ tidak berlaku selamanya. Ketentuan demikian bisa berubah dalam batas-batas (limits, hudu>d) tertentu. Bisa saja dalam kondisi tertentu, bagian itu menjadi 1:1.

Berdasarkan hal tersebut, pemikiran Syahrur penting untuk diteliti, tidak saja karena pembacaannya tentang hukum waris Islam yang berbeda dengan para fuqaha pada umumnya dan menimbulkan 'geger hukum Islam', melainkan juga karena model pembacaannya yang berbeda itu mengandung gagasan sekaligus tawaran orisinal yang patut dipahami dan diapresiasi.

Oleh karena itu, penelitian ini berupaya untuk menjawab beberapa permasalahan, yaitu pertama, bagaimana kritik Syahrur atas hukum waris Islam dan penemuannya? Dan kedua, bagaimana Syahrur merekontruksi suatu hukum dalam upaya menemukan hukum waris kontekstual?

\section{LITERATUR REVIEW}

Penelitian tentang pemikiran Syahrur bukanlah suatu yang baru. Meskipun demikian, nampaknya belum ditemukan penelitian yang secara spesifik meneliti rekonstruksi hukum waris Islam kontemporer ala Syahrur. Berikut beberapa karya yang terdokumentasikan terkait permasalahan yang dikaji, yaitu pertama,

${ }^{2}$ Wael B. Hallaq (Hallaq) menyebutkan bahwa sumbangan utama Shahrur terletak pada teori batas yang dimunculkannya. Lihat apresiasi Hallaq pada temuan Syahrur ini dalam Wael B. Hallaq, $A$ History of Islamic Legal Theories: An Introduction to Sunni Ushul Fiqh (Cambridge: Cambridge University Press, 1997), 47. 
Abdul Ghofur Anshori ${ }^{3}$ dalam bukunya yang berjudul "Hukum Kewarisan Islam di Indonesia: Eksistensi dan Adaptabilitas". Menurutnya, dalam sistem kewarisan bilateral antara garis keturunan laki-laki dan perempuan tidak dibedakan. Keduanya memiliki kekutan atau hak yang sama untuk mendapatkan harta warisan dari kedua orangtuanya dan kerabatnya. Karena itu, menurut Hazairin: pertama, ahli waris perempuan dan laki-laki sama-sama dapat meng-hijab ahli waris kelompok keutamaan yang lebih rendah; Kedua, garis kewarisan laki-laki sama kuatnya dengan garis perempuan. Karenanya, ashabah dan zawu al-arham tidak dikenal dalam sistem kewarisan bilateral. Ketiga, adanya ahli waris pengganti yang selalu mewarisitidak pernah tertutup oleh ahli waris lain (utama). Karena itu, cucu dapat mewaris bersama dengan anak ketika orang tuanya meninggal lebih dulu daripada kakeknya dengan bagian sama besarnya dengan bagian orang tuanya.

Kedua, William Robertson Smith ${ }^{4}$ dalam karyanya yang berjudul "Kinship and Marriage in Early Arabia". Atas karyanya ini, Smith disebut-sebut sebagai sarjana pertama yang melacak elemen-elemen dasar tertentu dalam hukum waris Islam dan kembali ke hukum adat kabilah pra-Islam. Intinya, menurut Smith, hukum waris Islam diambil atau berasal dari hukum adat tribal pra-Islam.

Dan ketiga, Abu Zayd ${ }^{5}$ dalam buku berjudul "Dekonstruksi Gender: Kritik Wacana Perempuan dalam Islam", yang diterjemahkan oleh Moch. Nur Ichwan dan Moch. Syamsul Hadi. Menurutnya, teks waris Islam harus dipahami makna dan signifikansinya. Dari keduanya, Abu Zayd

\footnotetext{
${ }^{3}$ Abdul Ghofur Anshori, Hukum Kewarisan Islam di Indonesia: Eksistensi dan Adaptabilitas (Yogyakarta: Ekonisia, 2005), 193.

${ }^{4}$ William Robertson Smith, Kinship and Marriage in Early Arabia (Cambridge: Cambridge University Press, 1885), 26-29.

${ }^{5}$ Nasr Hamid Abu Zayd, Dekonstruksi Gender: Kritik Wacana Perempuan dalam Islam, terj. Moch. Nur Ichwan dan Moch. Syamsul Hadi (Yogyakarta: SAMHA, 2003), 206-212.
}

menyimpulkan bahwa sebenarnya bagian laki-laki berjumlah dua bagian perempuan merupakan pembatasan dari anarki dan monopoli sekaligus menuju persamaan. Karena itu, bagi Abu Zayd, persamaan bagian dalam waris sebenarnya merupakan tujuan hukum Islam. lihat Nasr Hamid Abu Zayd, Dekonstruksi Gender: Kritik Wacana Perempuan dalam Islam, terj. Moch. Nur Ichwan dan Moch. Syamsul Hadi (Yogyakarta: SAMHA, 2003), terutama hlm. 206-212.

Dari ketiga literatur yang telah dipaparkan di atas, ternyata belum ada tinjauan secara khusus dan komprehensif tentang rekonstruksi hukum waris Islam kontemporer. Dengan menggunakan pendekatan kualitatif-normatif dan teknik analisis deskriptif ini, selain nantinya akan tergambar karakteristik pemikiran rekonstruksi hukum waris Islam, diharapkan penelitian ini juga akan mengungkapkan nuansa pembaharuan pemikiran hukum Islam sesuai dengan perkembangan saat ini. Di sinilah letak perbedaan penelitian ini dengan litratur-litratur yang telah dilakukan sebelumnya.

\section{METODOLOGI PENELITIAN}

Jenis penelitian yang digunakan adalah penelitian kepustakaan. Penelitian kepustakaan merupakan penelitian yang penemuanya didapatkan dengan mencari data dari berbagai literatur dan referensi yang berhubungan dengan materi pembahasan. $^{6}$

Metode yang digunakan dalam penelitian ini adalah metode kualitatif, dimaksud sebagai metode penelitian yang temuan-temuannya tidak diperoleh melalui prosedur statistic atau bentuk hitungan lainnya. ${ }^{7}$ Penelitian Kualitatif menurut Flick ialah specific relevance to the study of social reletions, owing to the fact of the pluralization of life worlds. Penelitian kualitatif adalah keterkaitan spesifik pada

\footnotetext{
${ }^{6}$ Moh. Nazir, Metode Penelitian (Bandung: Ghalia Indonesia, 2003), 193.

${ }^{7}$ Imam Gunawan, Metode Penelitian Kualititaif (Jakarta: Bumi Aksara, 2015), 80.
} 
studi hubungan sosial yang berhubungan dengan fakta dari pluralisasi dunia kehidupan. ${ }^{8}$

Pendekatan penelitian yang dilakukan menggunakan pendekatan kualitatif normatif, yaitu sebagaimana cara yang digunakan dalam penelitian hukum yang dilakukan dengan cara meneliti bahan pustaka yang ada. ${ }^{9}$

Sumber data yang diperlukan adalah data primer dan data sekunder. Data primer didapatkan dari hasil karya Muhammad Syahrur tentang rekonstruksi hukum waris Islam kontemporer. Adapun data sekunder yang digunakan di sini yaitu, skripsi, jurnal, dan website yang terkait.

Teknik pengumpulan data merupakan langkah yang paling strategis dalam penelitian, karena tujuan utama dari penelitian adalah mendapatkan data. ${ }^{10}$ Peneliti melakukan teknik pengumpulan data dengan melakukan penelitian terhadap berbagai literatur yang dilakukan untuk mencari konsep yang ada relevansinya dengan topik pembahasan melalui pengkajian buku-buku, jurnal, majalah, serta pendapat para ahli secara tidak langsung, yang kemudian akan dianalisis secara mendalam. Selain itu, penelitian ini menggunakan teknis analisis deskriptif, yaitu analisis dengan cara memaparkan data yang telah terkumpul dan tersusun secara sistematis. ${ }^{11}$

\section{BIOGRAFI SINGKAT MUHAMMAD SYAHRUR}

Muhammad Syahrur dilahirkan di Damaskus, Syiria, pada 11 April 1938 M. Ayahnya bernama Deib Ibn Syahrur dan ibunya Siddiah binti Salih Filyun. Syahrur

\footnotetext{
${ }^{8}$ Imam Gunawan, Metode Penelitian Kualitatif, 81.

${ }^{9}$ Suerjono Sukanto dan Sri Mamudji, Penelitian Hukum Normatif Suatu Tinjauan Singkat, Cet. 11 (Jakarta: PT. Raja Grafindo Persada, 2009), 13-14.

${ }^{10}$ Sugiyono, Metode Penelitian Kuantitatif, Kualitatif Dan R\&D (Bandung: Alfabeta, 2013), 224.

11 Jalaludin Rahmat, Metodologi Hukum (Jakarta: Fajar Agung, 1997), 134.
}

menikah dengan Azizah dan memperoleh lima anak (Tariq, Lays, Rima, Basil, dan Masun) dan dua cucu (Muhammad dan Kinan). ${ }^{12}$

Karir intelektual Syahrur dimulai dari pendidikan dasar dan menengah yang ditempuhnya di lembaga pendidikan Abdurrahman al-Kawakibi, Damaskus (selesai tahun 1957 M). Setelah itu, tepatnya Maret 1957 M, Ia melanjutkan studi dalam bidang Teknik Sipil ke Moskow, Uni Soviet (sekarang Rusia) dengan beasiswa dari pemerintah Syiria. ${ }^{13}$ Di Moskow, Ia mulai berkenalan dengan teori dan praktik Marxis: dialektika materialisme dan materialisme historis dan tradisi Formalisme Rusia yang berakar pada Strukturalisme Linguistik. Di Moskow pula, Ia mengaku dipengaruhi oleh pemikiran Friedrich Hegel dan Alfred North Whitehead. Syahrur sendiri meraih gelar diploma di bidang tersebut pada tahun 1964. Sementara program Megister dan doktor di bidang mekanika pertanahan dan teknik bangunan didapat dari University College, Dublin, Irlandia. Hingga kini, Syahrur masih tercatat menjadi salah satu staf pengajar di Fakultas Teknik Sipil Universitas Damaskus dalam bidang Mekanika Tanah dan Geologi.

Meski bidang utama Syahrur adalah teknik, namun tidak menghalanginya untuk mendalami disiplin ilmu lain sperti filsafat. Hal ini, terutama terjadi ketika ia bertemu dengan Ja'far Dakk al-Bab, rekan sealmamater di Syiria dan seprofesi di Damaskus. Pertemuannya itu telah memberikan arti cukup besar pada pemikirannya dalam al-Kita>b wa alQur'an: Qira'ah Mu'a>syirah (1990), buku pertama Syahrur yang begitu kontroversial sekaligus mencuatkan namanya di deretan pemikir Islam terkemuka.

\footnotetext{
${ }^{12}$ Ahmad Zaki Mubarak, Pendekatan Strukturalisme Linguistik dalam Tafsir al-Qur'an Kontemporer "ala” M. Syahrur (Yogayakarta: eLSAQ Press, 2007), 137.

${ }^{13} \mathrm{M}$. Aunul 'Abied Shah dan Hakim Taufik, “Tafsir Ayat-ayat Gender dalam al-Qur'an; Tinjauan terhadap Pemikiran Muhammad Syahrur dalam "Bacaan Kontemporer", dalam M. Aunul 'Abied Shah, et.al., Islam Garda Depan Mosaik Pemikiran Islam Timur Tengah (Bandung: Mizan, 2001), 237.
} 
Kesungguhan Syahrur di bidang keislaman ditunjang oleh penguasaan bahasanya: Inggris, Rusia dan Arab. Dengan modal inilah, Syahrur banyak belajar tentang Filsafat Humanisme, Filsafat Bahasa (khususnya linguistik modern), dan Semantika Bahasa Arab. ${ }^{14}$ Di bidang linguistik, Syahrur banyak belajar pada teman seprofesinya, Ja'far Dakk al-Bab. Syahrur sendiri berkeyakinan bahwa metode apa pun dan dari mana pun layak diuji dan dipakai sebagai alat bantu dalam memahami teks-teks keagamaan.

Dalam lapangan hukum Islam, Syahrur disebut-sebut sebagai tokoh utama yang memiliki konsep pembaruan ilmu ushul fikih paling revolusioner dan inovatif. Gagasan-gagasan Syahrur dianggap mampu menjawab berbagai persoalan dalam hukum Islam kontemporer, termasuk mengatasi problem pemahaman hukum Islam dalam teori double movement-nya Fazlur Rahman, ${ }^{15}$ yang menurut Hallaq memiliki kelemahan pada gerak kedua, persisnya pada bagaimana persisnya cara menderivasikan ideal moral yang telah ditemukan sebelumnya melalui gerak pertama kedalam kasus yang terjadi saat

\footnotetext{
${ }^{14}$ Bukti kuat atas minat Syahrur dalam mendalami berbagai bidang ilmu pengetahuan, misalnya, dalam bidang linguistic. Ia menekuni karya-karya linguis Arab, seprti al-Farra', Ibnu Faris, Abu Ali al-Farisi, Ibn Jinni, dan Abdul Qahir alJurjani, di samping karya-karya linguis Barat kontemporer seperti Toshihiko Izutsu dan Ferdinand de Saussure.

${ }^{15}$ Rahman menawarkan dua langkah dalam proses interpretasi, yakni dari dimulai situasi sekarang menuju situasi di mana al-Qur'an diturunkan, lalu kembali lagi ke masa sekarang. Proses ini kemudian dikenal dengan gerakan ganda (double movement), yaitu: pertama, berangkat dari kasus konkrit yang ada dalam al-Qur'an dengan mempertimbangkan kondisi sosial yang ada itu, lalu menuju untuk menemukan prinsip umum yang akan menjadi inti/generalisasi/prinsip semua ajaran. Kedua, membawa prinsip-prinsip umum ini kembali menuju kasus spesifik saat ini, dengan mempertimbangkan kondisi sosial yang ada dan dihadapi sekarang. Fazlur Rahman, Islam and Modernity: Tranformation of an Intellectual Tradition (Chicago: University of Chicago Press, 1982), 5-6.
}

ini. ${ }^{16}$ Selain itu, teori batas Syahrur dianggap sebagai temuan yang orisinil sekaligus menunjukan sumbangan terbesar Syahrur dalam pemikiran hukum Islam.

Di sisi lain, Syahrur nampak tidak berpijak pada paradigma ilmu ushul fikih yang dikenal sebelumnya, bahkan terkesan mencampakannya begitu saja. Syahrurdengan proyek "pembacaan kontmporernya-justeru menyusun teoriteori baru, seperti teori batas, yang dianggapnya lebih selaras dengan situasi dan kondisi masyarakat saat ini. Menurut Hallaq, gagasan-gagasan Syahrur tidak lepas dari latar belakang pendidikannya sebagai seorang insinyur teknik. Ini nampak dari pembacaannya terhadap al-Qur'an dan Sunnah yang banyak memanfaatkan ilmuilmu alam; khususnya matematika dan fisika. $^{17}$ Namun, orisinalitas gagasan Syahrur-ditambah lagi Syahrur yang masuk dalam kancah pemikiran Islam dengan tidak diperkirakan sebelumnyajusteru menghadapi penentangan yang massif, bahkan dari tokoh yang menaruh perhatian besar pada pembaruan pemikiran Islam semacam Abu Zayd. ${ }^{18}$

$$
\text { Meski demikian, gagasan- }
$$
gagasannya tetap mendapat banyak apresiasi. Salah satunya datang dari Hallaq. Hallaq bahkan mencoba meyakinkan umat Islam bahwa Syahrur tidak saja berhasil menyusun metodologi secara padu dan unik, tetapi juga berhasil menemukan metodologi lebih sesuai dengan pemikiran yang Islami.

\footnotetext{
${ }^{16}$ Wael B. Hallaq, A History of Islamic Legal Theories: An Introduction to Sunni Usul al-Fiqh, 245.

${ }^{17}$ Wael B. Hallaq, "Membaca Teori Batas Muhammad Syahrur," pengantar dalam Muhammad Syahrur, Prinsip dan Dasar Hermeneutika Hukum Islam Kontemporer, terj. Sahiron Syamsuddin dan Burhanudin Dzikri (Yogyakarta: eLSAQ Press, 2007), 3 .

${ }^{18}$ Uraian singkat tentang resistensi terhadap Syahrur, lihat Andreas Christman, "Bentuk Teks (Wahyu) Tetap, Tetapi Kandungannya (Selalu) Berubah: Tekstualitas dan Penafsirannya dalam AlKitab wa Al-Qur'an," pengantar dalam Muhammad Syahrur. Metodologi Fiqih Islam Kontemporer, terj. Sahiron Syamsuddin dan Burhanudin (Yogyakarta: eLSAQ Press, 2004), 21-24.
} 
Metodologi Syahrur, tegas Hallaq, tidak tunduk pada konsep yang dipahami secara tekstual, tetapi ia memadukan analisis tekstual dan kontekstual untuk menjadikan hukum yang humanis. ${ }^{19}$

Selain sebagai sosok kontroversial, Syahrur juga merupakan penulis produktif. Selain buku al-Kita>b wa al-Qur'an: Qira'ah Mu'a>syirah, Syahrur menulis buku-buku yang terfokus pada proyek yang disebutnya sebangai "Qira'ah $M u$ 'a $>$ syirah" atau pembacaan kontemporer terhadap ajaran Islam, yaitu; Dira $>$ sat alIsla>miyyah al-Mu'a>syirah fi ad-Daulah wa al-Mujtama' (1994); al-Isla $>m$ wa alI>ma>n: Manz\}u>mah al-Qiya>m (1996); dan Nahwu Us\}u>l Jadi>dah li al-Fiqh alIslami >: Fiqh al-Mar'ah (2000). Selain itu, ia juga menulis banyak artikel, di antaranya; Applying the Concept of Limit to the Right of Muslim Woman, ${ }^{20}$ Divine Text and Pluralism in Muslim Societies, Reading the Religious Text, The Book and The Quran, Haula al-Qira>'ah al-Mu'a>syirah li alQur'an, dan Ta'liq ala al-Kutu>b wa alMaqa>lat wa al-Rudu>d allati> Sudirat haula "al-Kita>b wa al-Qur'an Qira'ah Mu'a>syirah".

\section{PEMBAHASAN DAN DISKUSI Rekonstruksi Muhammad Syahrur dalam Hukum Waris Islam}

Sarjana kontemporer yang juga melakukan telaah kritis atas hukum waris Islam adalah Syahrur. Dalam bukunya, Nahw Ushul Jadidah li al-Figh al-Islami, ${ }^{21}$ Syahrur menyebut berbagai persoalan hukum waris yang selama ini dimapankan oleh para fuqaha. Persoalan-persoalan tersebut adalah; (1) pengutamaan masalah waris dan

\footnotetext{
${ }^{19}$ Wael B. Hallaq, "Membaca Teori Batas Muhammad Syahrur," pengantar dalam Muhammad Syahrur, Prinsip dan Dasar Hermeneutika Hukum Islam Kontemporer, 16.

${ }^{20} \mathrm{Http}$ ://Www.Free-Minds.Org/ApplyingConcept-Limits-Rights-Muslim-Women. Artikel ini diakses pada tanggal 11 November 2017.

${ }^{21} \mathrm{Buku}$ ini diterjemahkan ke dalam bahasa Indonesia oleh Sahiron Syamsuddin dan Burhanudin. Uraian tentang problem hukum waris tersebut lihat, Muhammad Syahrur, Metodologi Fiqih Islam Kontemporer, 321-322.
}

hukumnya, tetapi mengesampingkan wasiat beserta hukum yang mengikutinya; (2) memaksakan penghapusan (nasakh) ayatayat wasiat; (3) mencampurkan dua konsep yang berbeda, yakni al-hazz (jatah pada warisan) dengan al-nasib (bagian pada wasiat), sehingga memunculkan kerancuan pemahaman antara ayat-ayat waris dan ayatayat wasiat; (4) tidak ada pembedaan antara keadilan universal dalam ayat-ayat waris dan keadilan spesifik dalam ayat-ayat wasiat; padahal ketentuan yang bersifat umum tidak berarti menghapus ketentuan yang bersifat khusus; (5) firman Allah: $f a$ in kunna nisa'an fawqa itsnatayni dimaknai dengan pengertian: "Jika kalian (para perempuan) berjumlah dua atau lebih." Padahal, ayat tersebut tidak bisa dipahami dengan pengertian yang tidak logis tersebut; (6) terma "al-walad" dalam ayat-ayat waris dipahami sebagai anak laki-laki, bahwa hanya anak laki-laki-lah yang menjadi sebab terhalang dan tertutupnya suatu pewarisan pada pihak lain. Pemahaman ini, menurut Syahrur, merupakan reduksi besar-besaran; (7) masih dipertahankannya konsep 'aul dan radd, sehingga mengakibatkan beberapa pihak menerima harta waris secara berlebihan, sementara yang lain haknya dikurangi secara tidak adil; (8) Para cucu, meskipun yatim, tidak diperbolehkan menerima bagian warisan dari kakek mereka-dalam keadaan sepeninggal ayahnya-meskipun cucu itu dalam ayat waris; dan (9) pemberian bagian tertentu kepada pihak yang sama sekali tidak disebut dalam ayat-ayat waris, seperti paman (dari pihak bibi). Menurut Syahrur, penetapan ini sebagai akibat dari nalar sosial dan politik patriarkis.

Syahrur berupaya menyelesaikan problem-problem hukum waris tersebut, termasuk tentang bagian waris laki-laki yang mendapat dua kali bagian perempuan. Uraian di bawah ini akan sedikit menggambarkan pemikiran Syahrur dalam menyelesaikan beberapa persoalan waris, yakni terkait dengan hubungan wasiat dan waris, konsep nasakh ayat-ayat waris terhadap ayat-ayat wasiat, dan teori hudud Syahrur dalam pembagian hukum waris. 


\section{Hubungan wasiat dengan waris}

Salah satu yang menjadi sasaran kritik Syahrur, sebagaimana disinggung di atas, adalah kecenderungan para fuqaha yang meperlakukan hukum wasiat tidak lebih penting dari hukum waris. Bersebrangan dengan para ulama pada umumnya, Syahrur menegaskan bahwa wasiat seharusnya lebih diutamakan daripada waris, karena ia berpotensi untuk mewujudkan keadilan yang khusus terkait dengan kepentingan pribadi dan efektivitas dalam pemanfaatan harta, pengembanga relasi sosial dan hubungan kekeluargaan, di samping mencerminkan kepedulian si pewasiat terhadap kepentingan pihak lain. Bagi Syahrur, hal ini dibuktikan dengan realitas obyektif bahwa ketika seseorang memiliki potensi atau situasi khusus dalam keluarga, orang-orang terdekat dan kepedulian satu-pihak kepada pihak lain akan tampak. Sekali lagi, karena dalam wasiat tidak dikenal kemiripan atau kesamaan posisi semacam ini. Berbeda dalam waris, di mana terdapat keserupaan posisi pada seluruh manusia. Bagian dalam hukum waris ditentukan oleh posisi seseorang dalam konstelasi pihak-pihak yang menerima harta (sebagai bapak, ibu, anak, dan sebagainya). ${ }^{22}$

Dari perbedaan ini, Syahrur menegaskan bahwa keserupaan merupakan sifat yang umum, sementara perbedaan adalah sifat yang khusus. Waris dan wasiat menggambarkan relasi dialektis antara keserupaan dan perbedaan. Komunitas manusia sendiri, menurut Syahrur, berdiri di atas keragaman kondisi penghidupan, keluarga, sosial, dan kebutuhan hidup. Karena itu, dalam relasi ini, wasiat semestinya lebih diutamakan.

Syahrur mendasakan keutamaan wasiat dari waris pada ayat-ayat wasiat, misalnya, pada surat al-Baqarah (2): 180, yaitu "Diwajibkan atas kamu, apabila seorang di antara kamu kedatangan (tanda-

\footnotetext{
${ }^{22}$ Muhammad Syahrur, Metodologi Fiqih Islam Kontemporer, 325.
}

tanda) maut, jika ia meninggalkan harta yang banyak, berwasiat untuk ibu-bapak dan karib kerabatnya secara ma'ruf, (ini adalah) kewajiban atas orang-orang yang bertakwa." Bagi Syahrur, pembebanan untuk berwasiat tersebut ditujukan kepada semua orang yang bertakwa di muka bumi ini.

Lalu, kepada siapa yang bisa menjadi sasaran wasiat? Syahrur menyebut para ahli wasiat secara gradual, yaitu dari kedua orang tua biologis dan kerabat, kedua orang tua sosiologis dan kerabat, anak-anak yatim dan orang-orang miskin, dan kelompok generasi lemah. Untuk kategori terakhir, Syahrur menyebutnya terdiri dari anak-anak cacat, anak yang belum memasuki usia produktif di antara anakanak lainnya yang dewasa dan produktif, orang tua lanjut usia dan sakit, pasangan (isteri) yang sakit, dan anak perempuan yang telah menikah, tapi masih hidup dalam kemiskinan/kekurangan di antara anak-anak perempuan lainnya yang sudah menikah dan hidup berkecukupan. ${ }^{23}$

Sementara itu, terkait penentuan wasiat, menurut Syahrur, bersifat luas. Maksudnya, ketentuan kepada siapa wasiat diberikan sepenuhnya menjadi hak pewasiat. Tidak ada batasan ataupun ketentuan yang ditetapkan syari'at kecuali standar ketakwaan dan rasa takut kepada Allah swt. Misalnya, bisa saja pewasiat memberikan bagian lebih besar kepada anaknya yang cacat daripada anaknya yang sehat. Begitu pula dengan bagian yang diberikan pada anak kecil dan belum selesai masa studinya, hendaknya lebih besarga daripada bagian yang diberikan kepada anaknya yang sudah lulus sekolah dan dewasa atau sudah bekerja.

Untuk menegaskan keluasan wasiat, Syahrur mengungkapkan tiga hal sebagai tambahan, yaitu; pertama, tidak ada pembedaan terhadap sasaran wasiat atas dasar jenis kelamin; kedua, mengutamakan pelaksanaan wasiat, meski harta yang ditinggalkan sedikit; ketiga, bagian yang diberlakukan dalam wasiat adalah porsi

\footnotetext{
${ }^{23}$ Muhammad Syahrur, Metodologi Fiqih Islam Kontemporer, 326-329.
} 
yang ditentukan oleh pewasiat. Artinya, penentuan porsi (an-nasb) termasuk dalam wilayah otoritas manusia. Berbeda dengan bagian waris berapa jatah (al-hazz) yang ditentukan oleh Allah, dan karenanya menjadi hak otoritas Allah untuk menentukannya. ${ }^{24}$

Terkait masalah ayat-ayat wasiat yang menurut banyak kalangan telak dinasakh oleh ayat-ayat waris, Syahrur menunjukan ketidaksetujuannya. Baginya, tidak ada nasakh dalam al-Qur'an, termasuk pada ayat-ayat wasiat. Pandangan demikian, menurut Syahrur, merupakan penodaan dan pereduksian terhadap karakter universal ajaran al-Qur'an itu sendiri. ${ }^{25}$

\section{Teori hudud dalam pembagian warisan}

Teori hudud (teori batas) merupakan gagasan orisinil Syahrur. Secara sederhana teori batas Syahrur menegaskan bahwa Allah telah menetapkan konsep-konsep hukum yang maksimum dan minimum, dan manusia bergerak dari dan dalam kedua batasan tersebut. Untuk menjelaskan teorinya, Syahrur menetapkan enam model teori batas, yaitu; pertama, ketentuan hukum yang hanya memiliki batas minimal. Hal ini misalnya berlaku pada ayat tentang perempuan-perempuan yang tidak boleh dinikahi (QS. al-Nisa (4): 22-23), jenis-jenis makanan yang diharamkan (QS. al-Maidah (5): 3; al-An'am (6): 145-156), utang piutang (QS. al-Baqarah (2): 283-284), dan ayat tentang pakaian wanita (QS. al-Nisa (4): 31); kedua, ketentuan hukum yang hanya memiliki batas maksimal. Hal ini berlaku, misalnya, pada ayat pencurian (QS. al-Maidah (5): 38); ketiga, ketentuan hukum yang memiliki batas minimal dan batas maksimal sekaligus. Hal ini terdapat dalam persoalan hukum waris (QS. al-Nisa (4): 1114 dan 176) dan persoalan poligami (QS. alNisa (4): 3); keempat, ketentuan hukum yang memiliki batas minimal dan maksimal

\footnotetext{
${ }^{24}$ Muhammad Syahrur, Metodologi Fiqih Islam Kontemporer, 329-330.

${ }^{25}$ Muhammad Syahrur, Metodologi Fiqih Islam Kontemporer, 333.
}

sekaligus, tetapi dalam satu titik. Maksudnya, tidak ada alternatif hukum lain. Ini berlaku pada hukuman zina, yaitu seratus kali jilid (QS. al-Nur (24): 2); kelima, ketentuan hukum yang memiliki batas maksimal dengan satu titik yang cenderung mendekati garis lurus tapi tidak ada persentuhan. Ini berlaku bagi hubungan pergaulan laki-laki dan perempuan yang dimulai dari saling tidak menyentuh hingga hubungan yang hampir mendekati zina; dan keenam, ketentuan hukum yang memiliki batas maksimal positif dan tidak boleh dilampaui dan batas minimal negatif yang boleh dilampaui. Hal ini berlaku dalam persoalan kebendaan manusia. Batas maksimal yang bernilai positif berupa riba, sementara zakat adalah batas minimal yang bernilai negatif yang boleh dilampaui. ${ }^{26}$ Dengan demikian, waris dalam perspektif Syahrur merupakan hukum yang memiliki batas minimal sekaligus batas maksimal.

Dalam surat al-Nisa (4): 11, menurut Syahrur, misalnya, terdapat tiga batas. Pertama, batas maksimal bagian kelompok anak laki-laki adalah $(66,6 \%)$-dua kali lipat bagian perempuan-dan batas minimal bagi anak perempuan $(33,3 \%)$. Hal ini didasarkan pada Firman Allah swt. "lidzdzakari mitslu hazhzh al-untsayayn" (bagi laki-laki sebanding dengan bagian dua orang perempuan). Batas ini berlaku ketika perempuan tidak ikut menanggung beban ekonomi keluarga. Artinya, jika beban ekonomi keluarga sepenuhnya (100\%) ditanggung pihak laki-laki, sedangkan pihak perempuan sama sekali tidak terlibat $(0 \%)$, maka bagian minimal perempuan adalah $33,3 \%$, sedangkan bagian laki-laki maksimal 66,6\%. Karena itu, jika kita memberi laki-laki sebesar $75 \%$ dan perempuan $25 \%$, kita telah melanggar batasan yang ditetapkan oleh Allah swt. Namun, jika kita membagi $60 \%$ bagi lakilaki dan $40 \%$ bagi perempuan, kita tidak melanggar batasan hukum Allah swt.,

\footnotetext{
${ }^{26}$ Muhammad Syahrur, Prinsip dan Dasar Hermeneutika Hukum Islam Kontemporer, 31-49.
} 
karena kita masih berada di antara batasbatas hukum Allah swt., tersebut. ${ }^{27}$

Sebagaimana ditegaskan Syahrur, adanya batas minimal bagi perempuan dan maksimal bagi laki-laki ini pada gilirannya berkonsekuensi pada terbukanya pintu berijtihad untuk kaum Muslim, untuk bergerak di antara batasan-batasan tersebut sesuai dengan kondisi obyektif yang melingkupinya. Karena itu, pada saat yang sama, ijtihad menerapkan prinsip 'mendekat' di antara dua batasan tersebut, dimungkinkan hingga sampai pada titik keseimbangan di antara keduanya-masingmasing laki-laki dan perempuan menerima $50 \%$, sehingga posisinya sama $1: 1{ }^{28}$ Sampai titik ini, metodologi Syahrur memberikan efek bagi terciptanya dinamisasi hukum Islam. Hukum bisa berubah sesuai dengan ketentuan Allah sekaligus sesuai konteks manusianya.

Namun, meski teori batas Syahrur mewadahi fleksibilitas hukum, bukan berarti hukum bisa diubah semaunya. Ia harus didasarkan atas kondisi pewarisan dan atau perkembangan latar historisnya. Seberapa dekat prosentase tersebut diterapkan harus didukung oleh data-data statistik yang lengkap, bukan atas dorongan emosional semata, baik dari pihak laki-laki maupun perempuan. Bagi Syahrur, hal demikian menunjukkan bahwa hukum Islam bersifat pasti dalam penentuan batas-batas hukumnya sekaligus berkarakter lentur dalam gerak ijtihad di antara batasanbatasan tersebut. Hal ini juga menunjukkan bahwa ijtihad harus didasarkan atas buktibukti material terperinci dengan selalu mempertimbangkan kemaslahatan manusia dan menerapkan kemudahan bagi masyarakat, bukan didirikan di atas landasan emosi atau pendapat seseorang. ${ }^{29}$

Dari uraian di atas, persoalan yang muncul adalah dari mana Syahrur mengetahui bahwa $33,3 \%$ adalah batasan

\footnotetext{
${ }^{27}$ Muhammad Syahrur, Prinsip dan Dasar Hermeneutika Hukum Islam Kontemporer, 40.

${ }^{28}$ Muhammad Syahrur, Prinsip dan Dasar Hermeneutika Hukum Islam Kontemporer, 41.

${ }^{29}$ Muhammad Syahrur, Prinsip dan Dasar Hermeneutika Hukum Islam Kontemporer, 41.
}

minimal dari perempuan dan $66,6 \%$ adalah batasan maksimal bagi laki-laki, dan mengapa prinsip yang harus dipakai dalam ijtihad di antara batas-batas tersebut adalah prinsip mendekat bukan menjauh? Terhadap pertanyaan ini, tampaknya Syahrur sudah menyiapkan jawabannya. Bagi Syahrur, jawaban atas pertanyaan itu terletak pada karakter fitrah manusia sebagaimana ditegaskan dalam QS. al-Rum (30): $30 .^{30} \mathrm{Di}$ sisi lain, jika prinsip ini diuji dengan menanyakan pada sejuta Muslim yang mengetahui tentang ayat waris ini dan kepada sejuta Muslim yang sama sekali tidak mengetahui kaidah-kaidah hukum waris Islam, bagaimana pemecahan kasus tersebut, memakai prinsip mendekat atau menjauh? Tentu jawabannya adalah mendekat. Bagi Syahrur, hal ini sesuai dengan karakter alam semesta dan selaras dengan hukum matematika bahwa kurva lengkung yang memiliki titik balik maksimal dan titik balik minimal terentang di dalam batas-batas titik balik tersebut, bukan di luarnya. ${ }^{31}$

Kedua, batas minimal perempuan sebesar 2/3 dari harta peninggalan dengan syarat perempuan tersebut berjumlah lebih dari dua orang dan tidak ikut menanggung beban ekonomi keluarga. Hal ini didasarkan pada "fain kunna nisa' an fawqa itsnatayni falahunna tsulutsa ma tarak." Artinya, seorang anak perempuan minimal menerima bagian sebesar $1 / 3$ atau $33,3 \%$. Selain itu, Syahrur juga menyebutkan batas ketiga, yakni batas minimal bagi perempuan adalah setengah jika perempuan itu seorang diri. Hal ini didasarkan pada ayat yang menegaskan bahwa jika anak perempuan itu seorang saja, maka ia memperoleh separuh harta. Pada tahap selanjutnya, batas-batas yang diketengahkan Syahrur membawanya untuk menjadikan $33,3 \%$ sebagai batas

\footnotetext{
${ }^{30}$ Artinya: "Maka hadapkanlah wajahmu dengan lurus kepada agama Allah; (tetaplah atas) fitrah Allah yang telah menciptakan manusia menurut fitrah itu. Tidak ada peubahan pada fitrah Allah. (Itulah) agama yang lurus; tetapi kebanyakan manusia tidak mengetahui”.

${ }^{31}$ Muhammad Syahrur, Prinsip dan Dasar Hermeneutika Hukum Islam Kontemporer,41-42.
} 
minimal bagi kelompok perempuan dalam menerima harta warisan, dan bukan batas maksimal.

\section{Menggali Makna Asli dan Makna Kontemporer: Analisis Pemikiran Muhammad Syahrur}

Dari kajian tokoh tersebut bisa dilacak, apa yang sebenarnya dicari dan berusaha dipecahkan oleh Syahrur? Sebagai upaya penjelajahan awal, nampaknya Syahrur berusaha menggali apa yang disebut dengan makna asli (original meaning) dari hukum waris Islam. Dalam hal ini Syahrur berusaha melacak ketentuan-ketentuan hukum waris Islam yang dianggapnya sebagai sistem yang asli atau autentik.

Dengan demikian, Syahrur berusaha kembali kepada makna awal-secara leksikal dan gramatikal-dari ketentuan hukum waris yang ada. Hal ini nampak jelas dari pendekatan dan metode yang digunakan Syahrur dalam melacak makna-makna asli hukum waris itu. Syahrur dalam hal ini berusaha membuktikan bahwa ada sistem hukum waris yang asli, yang diturunkan kepada Nabi, yang berbeda dengan hukum waris sekarang ini. Selain itu, langkahlangkah Syahrur menunjukan bahwa ia merupakan tokoh revisionis yang memahami teks-teks kewarisan secara kritis, bahkan dalam tingkat tertentu meragukannya.

Selain berupaya menggali makna asli atau autentik, Syahrur juga menggali makna kontemporer yang dianggap sesuai dengan konteks modern. Apa yang diinginkan Syahrur adalah kesimpulankesimpulan yang hendak mewadahi nilainilai universal dalam Islam. Karena itu, jika makna dan kesimpulan hukum waris yang dihasilkan berbeda dengan makna literalnya, tidak menjadi persoalan. Bagi Syahrur, yang terpenting adalah menemukan batas-batas (maksimal dan minimal) dalam hukum waris, soal pembagian berapa itu sangat dipengaruhi oleh situasi dan kondisi. Karena itu, pada sisi ini, Syahrur nampak berada pada deretan tokoh yang mendekati hukum waris Islam secara kontekstual.

\section{KESIMPULAN}

Pemikiran Syahrur tentang waris dan wasiat menunjukkan beberapa temuan penting yang berbeda dengan para ulama atau sarjana lainnya. Tiga aspek yang bisa disebukan adalah; pertama, terkait relasi wasiat dan waris, menurut Syahrur, wasiat harus diutamakan daripada waris, karena lebih bisa mengakomodir nilai-nilai keadilan; kedua, tidak ada nasakh terhadap ayat-ayat wasiat; ketiga, teori hudud Syahrur berimplikasi pada runtuhnya pandangan lama bahwa bagian-bagian waris sama sekali tidak bisa diubah. Temuan Syahrur justeru sebaliknya bahwa bagianbagian itu berubah dan bersifat dinamis. Hemat Penulis, kajian Syahrur banyak menggunakan pendekatan linguistik dan scientifik modern. Kedua pendekatan ini banyak digunakan Syahrur dalam menemukan pemecahan-pemecahan dalam soal waris dan wasiat.

Selain itu, keunikan lain dari pemikiran Syahrur yaitu ketika ia merekontruksi hukum waris Islam yang dilakukan dengan keluar dari jeratan teksteks literal ajaran Islam untuk menemukan hukum waris yang kontekstual.

\section{DAFTAR PUSTAKA}

Abu Zayd, Nasr Hamid. Dekonstruksi Gender: Kritik Wacana Perempuan dalam Islam, terj. Moch. Nur Ichwan dan Moch. Syamsul Hadi. Yogyakarta: SAMHA, 2003.

Anshori, Abdul Ghofur. Hukum Kewarisan Islam di Indonesia: Eksistensi dan Adaptabilitas. Yogyakarta: Ekonisia, 2005.

Gunawan, Imam. Metode Penelitian Kualititaif. Jakarta: Bumi Aksara, 2015.

Hallaq, Wael B. A History of Islamic Legal Theories: An Introduction to Sunni Ushul Figh. Cambridge: Cambridge University Press, 1997.

Http://Www.Free-Minds.Org/ApplyingConcept-Limits-Rights-MuslimWomen. 
Mubarak, Ahmad Zaki. Pendekatan Strukturalisme Linguistik dalam Tafsir al-Qur'an Kontemporer "ala" M. Syahrur. Yogayakarta: eLSAQ Press, 2007.

Nazir, Moh. Metode Penelitian. Bandung: Ghalia Indonesia, 2003.

Rahman, Fazlur. Islam and Modernity: Tranformation of an Intellectual Tradition. Chicago: University of Chicago Press, 1982.

Rahmat, Jalaludin. Metodologi Hukum. Jakarta: Fajar Agung, 1997.

Shah, M. Aunul 'Abied dan Hakim Taufik. Islam Garda Depan Mosaik Pemikiran Islam Timur Tengah. Bandung: Mizan, 2001.

Smith, William Robertson. Kinship and Marriage in Early Arabia. Cambridge: Cambridge University Press, 1885.

Sugiyono. Metode Penelitian Kuantitatif, Kualitatif Dan R\&D. Bandung: Alfabeta, 2013.

Sukanto, Suerjono dan Sri Mamudji. Penelitian Hukum Normatif Suatu Tinjauan Singkat, Cet. 11. Jakarta: PT. Raja Grafindo Persada, 2009.

Syahrur, Muhammad. Al-Kitab wa alQur'an: Qira'ah Mu'ashirah. Damaskus: al-Ahali li ath-Thiba'ah li an-Nasyr wa at-Tauzi, 1992. -.Metodologi Fiqih Islam Kontemporer, terj. Sahiron Syamsuddin dan Burhanudin. Yogyakarta: eLSAQ Press, 2004. -. Prinsip dan Dasar Hermeneutika

Hukum Islam Kontemporer, terj. Sahiron Syamsuddin dan Burhanudin Zikri. Yogyakarta: eLSAQ Press, 2007. 